\title{
COMPARATIVE ANALYSIS OF PLATE GIRDER DESIGNS ON NON- COMPOSITE BRIDGES BETWEEN AASHTO LRFD BRIDGE DESIGN SPECIFICATIONS 2017 CODE WITH SNI 1729:2015 CODE
}

\author{
Donald, ESSEN, \\ Universitas Mercu Buana Jakarta, Indonesia, \\ donaldessenstmt@gmail.com \\ Nurul Musyafa Ulul, HIDAYAH, \\ Universitas Mercu Buana Jakarta, Indonesia, \\ syafagihan@gmail.com
}

\begin{abstract}
This study aims to the structural design of non-composite plate girders using AASHTO LRFD Bridge Design Specifications 2017 code compared to SNI 1729:2015 code. The span of the bridge used as the object of study is 40 meters with a width of 10 meters. In this study, plate girders are designed based on AASHTO code and SNI code, then also given the loading according to SNI 1725:2016 code, and in the analysis of the structure using CSi Bridge software to get the value of internal forces i.e. Moment Force $(\mathrm{Mu})$ of $3595.38 \mathrm{kNm}$ and Shear Force $\left(\mathrm{V}_{\mathrm{u}}\right)$ of $449.9968 \mathrm{kNm}$. The results obtained from this study are the non-composite bridge plate girder designed with AASHTO LRFD Bridge Design Specifications 2017 and SNI 1729:2015 obtained the stability requirements of strong boundary conditions flexure design. Then obtained Nominal Moment value $\left(\varnothing \mathrm{M}_{\mathrm{n}}\right)$ of $8016.843 \mathrm{kNm}$ for AASHTO LRFD Bridge Design Specifications 2017 and Nominal Moment value $(\varnothing \mathrm{Mn})$ of $6081.97 \mathrm{kNm}$ for SNI 1729:2015. From the values obtained it can be concluded that the two regulations produce a safe and strong plan as per the applicable provisions namely Moment $\left(M_{u}<\varnothing M_{n}\right)$.
\end{abstract}

Keywords: girder, AASHTO LRFD Bridge Design Specifications 2017, SNI 1729:2015, noncomposite, flexure design

\section{INTRODUCTION}

Indonesia is an archipelago with an area of water that reaches $64.97 \%$ of the total area (Bakosurtanal, 2014) (1). But that is not an obstacle for the central government to carry out the mandate of the nation listed in the Pancasila precisely in the 5th precept that reads "Social Justice for All Indonesian People".

Engineers in the construction world are expected to be able to actively participate in this national development effort. One type of construction that will be used in these efforts is a bridge. The bridge consists of many models and of course related to their respective functions. From a small bridge that serves to cross people located on the highway to a large bridge connecting inter-island that can be passed by motorized vehicles, such as motorcycles, cars, trucks, buses and so forth.

In its planning, the bridge itself is divided into several construction components such as:

a) Abutment

b) Bearings

c) Pier

d) Pile cap

e) Bored Pile

f) Girder (Composite / Non-Composite)

g) Deck

h) Highway

i) Sidewalks

j) Tension 
Of all the construction components, of course there are planning rules that are binding, standard and systematic. One of them is the component construction of the plate girders.

Fig. 1 Application Of Using Plate Girder Bridges On Japek II Elevated Toll Road

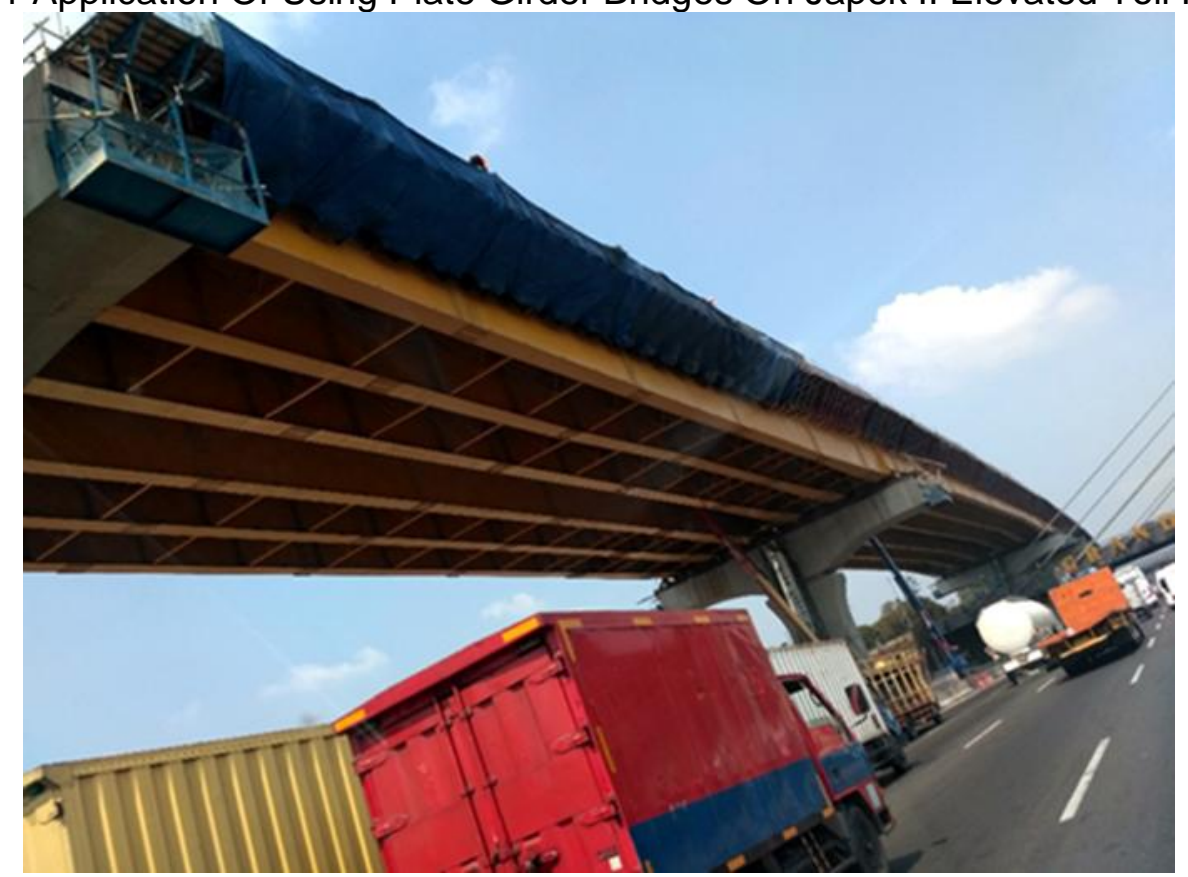

Source: Data in research, 2019

Plate girder is a large beam that is made from the arrangement of plate elements that are joined with a connecting tool to get a more efficient arrangement of material than that obtained with a wrought beam (rolled beam). Steel material has mechanical properties that are strong against compressive / tensile forces, but it should be noted that the stability of bending.

Basically, construction of large bridges will require relatively long stretches and it is also likely to be without a column / pier in the middle, therefore this plate girder selection is one of the solutions in implementing bridge construction work.

In the design of this steel frame bridge, it will use two bridge structure design regulations, namely using the AASHTO LRFD Bridge Design Specifications (American) and SNI (Indonesia), which in the end can be seen differences and similarities in the results of the design. The two construction regulations together show how to calculate and analyze plate girders. The differences and design similarities of the two reference rules will be discussed in my study this time.

The bridge is a part of the road that functions to connect between two separate roads due to obstacles such as rivers, valleys, seas, highways, and railroad tracks. The bridge is very vital function of human life, and has an important meaning for everyone. However, the level of importance is not the same for everyone, so it will be an interesting study material (Bambang Supriyadi, 2007) (2).

\section{RESEARCH METHODOLOGY}

The method that the author uses in this research is carried out by the method of literature study. Literature study is a description of the theoretical foundations relating to non-composite bridge planning. Literature studies are sourced from books, regulatory standards, and journals related to structural planning for non-composite bridges. 
Fig. 2 Bridge Cross Section

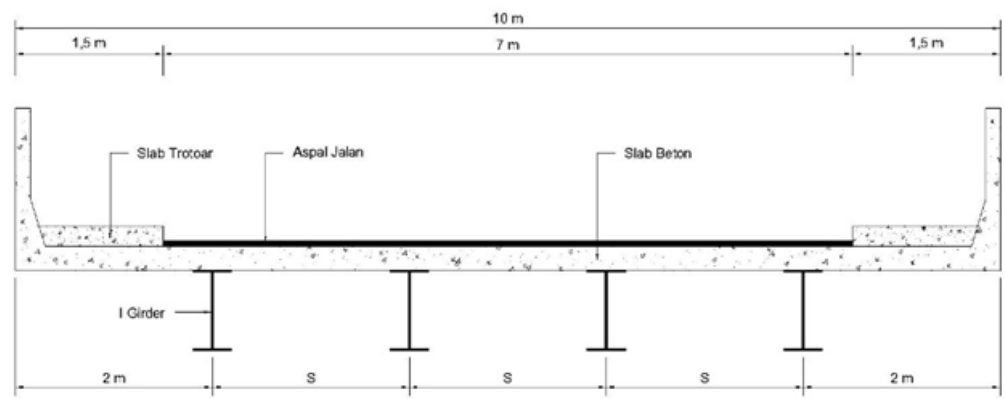

Source: Data in research, 2019

Assumption Technical Data
a. Bridge type
: Non-composite
b. Total bridge width
: $10 \mathrm{~m}$
c. Span length
: $40 \mathrm{~m}$

Fig. 3 Research Flow Chart

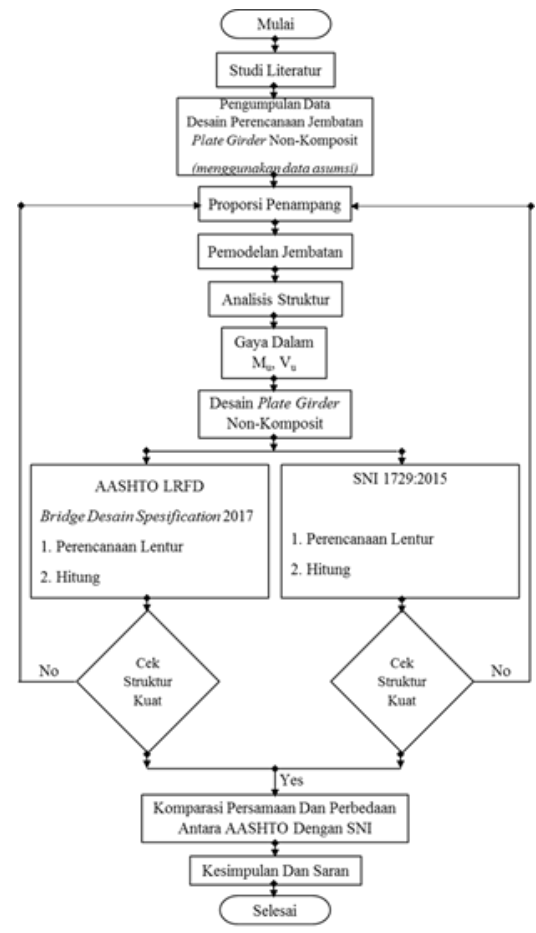

Source: Data in research, 2019

\section{RESULTS AND DISCUSSIONS}

\section{Calculation of Loading Non-Composite Steel}

1. Self Weight (MS)

\subsection{Steel Girder Weight}

The weight of the steel girder I was calculated automatically by the program, with $Y$ steel $=78.50 \mathrm{kN} / \mathrm{m}^{3}$

1.2 Deck Weight 
Deck has dimensions:

cross-sectional area $\quad A_{\text {deck }}=0.4 \mathrm{~m}^{2}$

Concrete specific gravity $Y_{\text {concrete }}=25 \mathrm{kN} / \mathrm{m}^{3}$

Then the deck load $\quad=A_{\text {deck }} \times Y_{\text {beton }}=10 \mathrm{kN} / \mathrm{m}$

1.3 Diaphragm Weight

Diaphragm has dimensions:

Diaphragm volume $\quad \mathrm{V}=0.006096 \mathrm{~m}^{3}$

Steel specific gravity $\quad Y_{\text {steel }}=78.5 \mathrm{kN} / \mathrm{m}^{3}$

2. Additional Dead Load / Utilities (MA)

2.1 Load Pavement

Concrete specific gravity $\quad Y_{\text {concrete }}=25 \mathrm{kN} / \mathrm{m}^{3}$

wide sidewalk $\quad A_{\text {sidewalk }}=0.189 \mathrm{~m} 2$

Load of sidewalk $\quad \mathrm{q}_{\text {sidewalks }}=25 \times 0.198=4.73 \mathrm{kN} / \mathrm{m}$ (per side)

2.2 Ralling Loads

Concrete specific gravity $Y_{\text {concrete }}=25 \mathrm{kN} / \mathrm{m}^{3}$

Wide railing concrete $\quad A_{\text {rall }}=0.196 \mathrm{~m} 2$

Load concrete railing $\quad$ qrall $=25 \times 0.196=4.90 \mathrm{kN} / \mathrm{m}$ (per side)

2.3 Asphalt Loads

Asphalt density $Y_{\text {asphalt }}=22.4 \mathrm{kN} / \mathrm{m}^{3}$

Asphalt thickness $t_{\text {asphalt }}=0.05 \mathrm{~m}$

Road width $\quad b_{\text {road }}=7 \mathrm{~m}$

Asphalt loads $\quad q_{\text {asphalt }}=22.4 \times 0.05 \times 7$

$=7.84 \mathrm{kN} / \mathrm{m}$ (per entire bridge width)

2.4 Concrete Screed Loads

Concrete specific gravity $\quad Y_{\text {concrete }}=25 \mathrm{kN} / \mathrm{m}^{3}$

Concrete screed area $\quad A_{\text {screed }}=0.35 \mathrm{~m}^{3}$

Concrete screed load $\quad \mathrm{q}_{\text {screed }}=25 \times 0.35=8.75 \mathrm{kN} / \mathrm{m}$ (per entire bridge width)

Then the total MA load $=35.85 \mathrm{kN} / \mathrm{m}$ (per entire bridge width)

And for the total MA load per girder $=\frac{35.85}{4}=8.96 \mathrm{kN} / \mathrm{m}$

3. "T" Truck Load Calculation (TT)

The truck load ' $T$ ' used is in accordance with SNI 1725: $2016^{[8]}$ as shown

Fig. 4 Truck Load ' $\mathrm{T}$ '
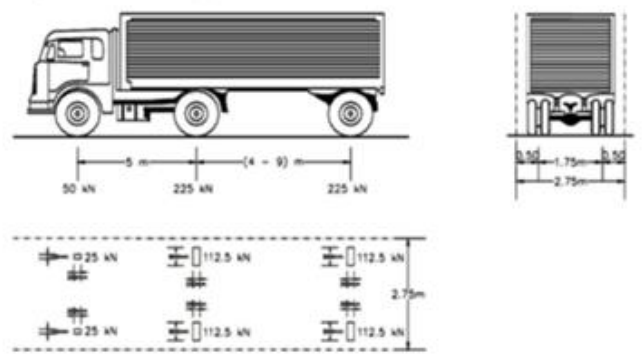

Dynamic load factor (FBD) for BGT is taken FBD $=0.300$

Front wheel weight

$$
\begin{gathered}
P_{r d}=25,000 \mathrm{kN} \\
P_{r b}=112,500 \mathrm{kN} \\
P_{1}=32.5 \mathrm{kN} \\
P_{2}=146.25 \mathrm{kN}
\end{gathered}
$$

Weight of front wheel + FBD

Rear wheel weight + FBD

4. Calculation of Lane Load ' $D$ '

The vehicle live load consists of lane load with the component load evenly distributed BTR and BGT line load as shown in Figure 4.3 BGT taken at $49 \mathrm{kN} / \mathrm{m}$. The lateral distribution of the "D" lane load is placed with an intensity of $100 \%$. The $q$ value of $B T R$ is determined from the following equation:

If $L \leq 30 \mathrm{~m} \rightarrow \mathrm{q}=9.0 \mathrm{kPa}$

If $L>30 \mathrm{~m} \rightarrow \mathrm{q}=9.0\left(0.5+\frac{15}{L}\right) \mathrm{kPa}$ 
Fig. 5 Lane Load 'D'

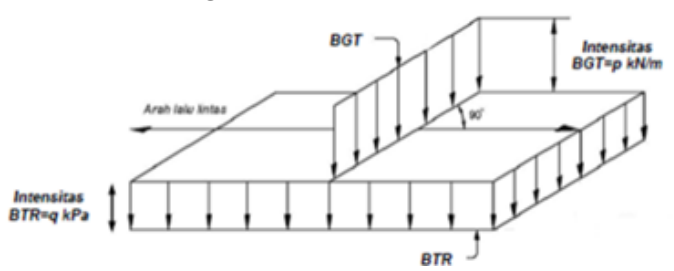

Lane density factors must be calculated according to Table 3.1

Table 3.1 Lane Density Factors

\begin{tabular}{|c|c|}
\hline $\begin{array}{c}\text { Jumlah lajur yang } \\
\text { dibebani }\end{array}$ & $\begin{array}{c}\text { faktor kepadatan } \\
\text { lajur }\end{array}$ \\
\hline 1 & 1,2 \\
\hline$\geq 2$ & 1 \\
\hline
\end{tabular}

Evenly distributed load intensity (BTR) $\quad \mathrm{q}=7,875 \mathrm{KPa}=\mathrm{kN} / \mathrm{m}^{2}$

Centralized line load intensity (BGT) $\quad p=49,000$

Dynamic load factor (FBD) for BGT is taken FBD $=0.300$

Load evenly distributed (BTR)

Central line load (BGT) + (FBD)

$\mathrm{q}=14.40 \mathrm{kN} / \mathrm{m}$

5. Pedestrian Loads

$\mathrm{p}=109.76 \mathrm{kN} / \mathrm{m}$

All sidewalk components wider than $600 \mathrm{~mm}$ must be planned to carry pedestrian loads with an intensity of $5 \mathrm{kPa}$.
a. Sidewalk width
$\mathrm{b}_{\mathrm{sw}}=1.50 \mathrm{~m}$
b. Intensity of pedestrian loads
$\mathrm{PTP}=5.00 \mathrm{kN} / \mathrm{m}^{2}$

Application Load On Steel Girder Composite Modeling

1. Application load of asphalt on the bridge

Fig 6. Modeling loading asphalt $5 \mathrm{~cm}$

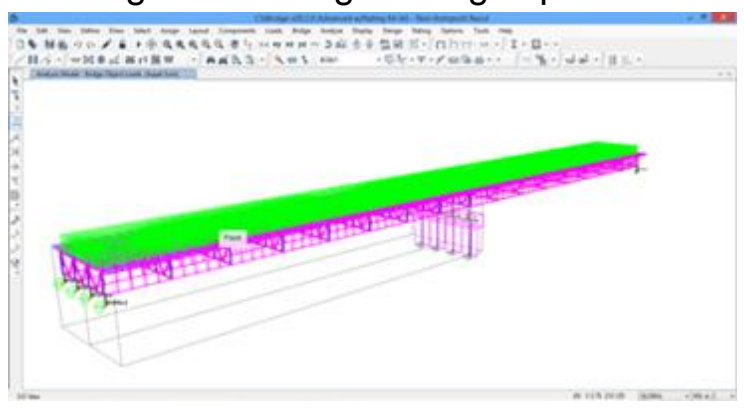

2. Application load on the left side of the pedestrian bridge

Fig. 7 Modeling 3D pedestrian loading Left

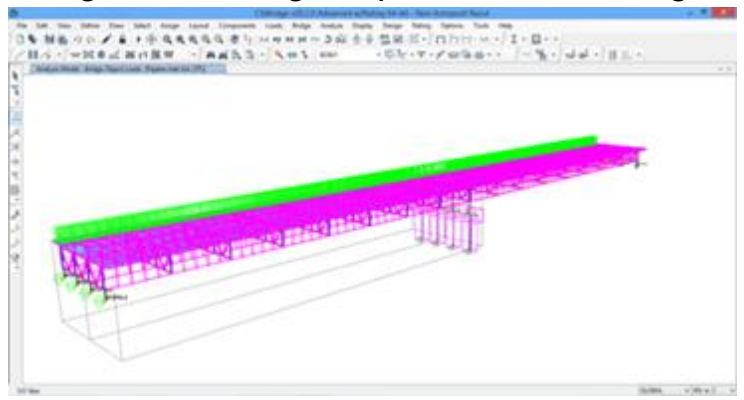


3. Application load on the right side of the pedestrian bridge

Fig. 8 Modeling pedestrian loading right

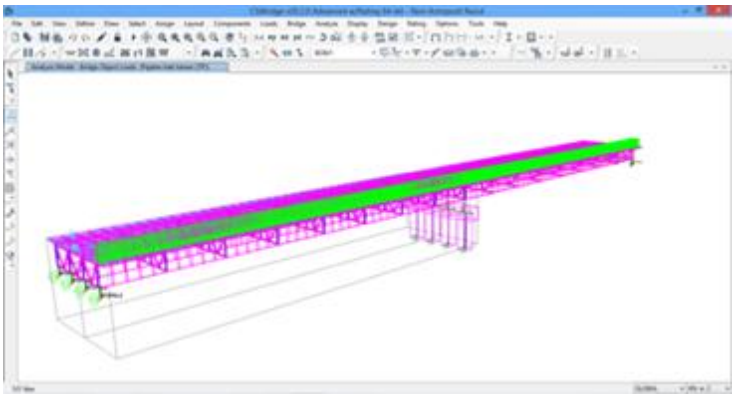

4. Applications load concrete pavement on bridges

Fig. 9 Modeling loading MA - pavement

Load Combination

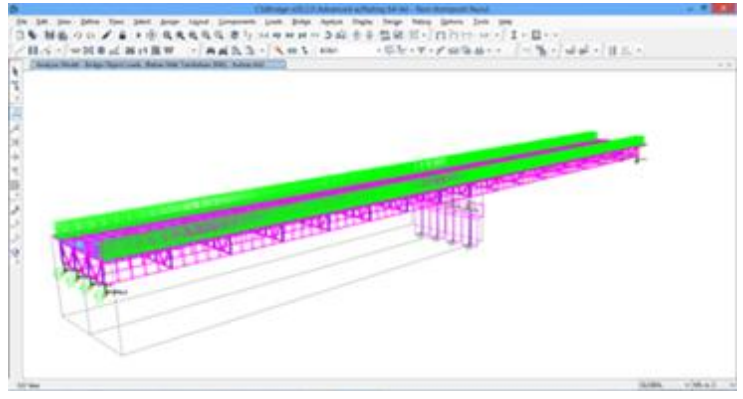

The combination of loading for Strong Boundary Conditions must comply with SNI 1725: 2016 as given in Table 3.2 as follows:

Table 3.2 Combination of Load and Load Factor

\begin{tabular}{|c|c|c|c|c|c|c|c|c|c|c|c|c|}
\hline \multirow[b]{2}{*}{$\begin{array}{l}\text { Kevodan } \\
\text { Buxas }\end{array}$} & \multirow{2}{*}{$\begin{array}{l}M S \\
M A \\
M A \\
P A \\
P R \\
A H \\
S H\end{array}$} & \multirow{2}{*}{ 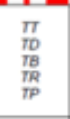 } & & \multirow[b]{2}{*}{$E W_{1}$} & \multirow[b]{2}{*}{ EW } & \multirow[b]{2}{*}{ Bf } & \multirow[b]{2}{*}{$E U_{b}$} & \multirow[b]{2}{*}{ TG } & \multirow[b]{2}{*}{$E S$} & \multicolumn{3}{|c|}{$\begin{array}{c}\text { Gunaten sainh } \\
\text { sane }\end{array}$} \\
\hline & & & & & & & & & & $E 0$ & $\pi c$ & $n$ \\
\hline Kuxi 1 & $r_{0}$ & 10 & .1 .00 & $\cdot$ & $\cdot$ & 1.00 & 0.50120 & $y_{n}$ & $Y_{s}$ & $\cdot$ & - & $\cdot$ \\
\hline Koux: : & $r_{0}$ & 1.4 & 1,00 &. &. & 1,00 & $0 \operatorname{sen}, 20$ & $7 \mathrm{~s}$ & $y_{e}$ & $\cdot$ & $\cdot$ &. \\
\hline $20 \times x=$ & $T_{0}$ & 7 & $1 . \infty$ & 100 & . & 1.00 & $0 \operatorname{sen} 20$ & $y_{n}$ & $y_{6}$ & $\cdot$ & - & $\cdot$ \\
\hline $\operatorname{kax} N$ & $y_{0}$ & . & 1.00 & $\cdot$ & $\cdot$ & 1.00 & 0.501 .20 & $\cdot$ & $\cdot$ & $\cdot$ & $\cdot$ & $\cdot$ \\
\hline $\operatorname{koux} \mathrm{V}$ & $r_{p}$ & . & $1, \infty$ & 0.40 & 1,00 & 1,00 & $0 \operatorname{sen} 20$ & $y_{v}$ & $Y_{6}$ & $\cdot$ & $\cdot$ & $=$ \\
\hline Extem I & $y_{0}$ & $y_{\infty}$ & 1.00 & . & . & 1.00 & . & $\cdot$ & $\cdot$ & 10 & $\cdot$ & $\therefore$ \\
\hline Batem I & $y_{6}$ & 0.50 & 1.00 & $\cdot$ &. & 1.90 &. & $\cdot$ & . & $:$ & 80 & 10 \\
\hline \begin{tabular}{|l}
$\sin _{0}$ \\
$\operatorname{lin}$
\end{tabular} & 1.00 & 1.00 & 1,00 & 0.00 & 1.00 & 1,00 & 1.001 .20 & $y_{w}$ & $y_{6}$ & $\cdot$ &. &. \\
\hline bin & 1.00 & 1.00 & 1.00 & - & $\cdot$ & 1.00 & 1.001 .20 & $\cdot$ & $\cdot$ & $\cdot$ & $\cdot$ & $\cdot$ \\
\hline $\lim _{\operatorname{lin}}$ & 1.00 & 0.00 & $1, \infty$ &. & $\cdot$ & 1,00 & 1.00120 & $7 \%$ & $Y_{6}$ & $\cdot$ & $\cdot$ & $\cdot$ \\
\hline ben & 100 & $\cdot$ & 1.00 & 0.0 & 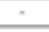 & 1,00 & 1.001 .20 & $\cdot$ & 100 & $\cdot$ &. & 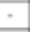 \\
\hline 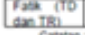 & $\cdot$ & Q.rs & $\cdot$ & . & $\cdot$ &. & - & 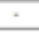 & . & $\cdot$ & $\cdot$ & $\cdot$ \\
\hline
\end{tabular}

Cross Section Proportion

Determining the Cross-Section Proportion

$\frac{d}{L}=\frac{1}{25}$

$d=\frac{L}{30}=\frac{40000 \mathrm{~mm}}{25}=1600 \mathrm{~mm}$

Raise the $10 \%$ height of the girder for SNI vehicle loads obtained:

$d+(d x 10 \%)=1600+(1600 \times 10 \%)=11760 \mathrm{~mm}$

Then take grades $d=1800 \mathrm{~mm}$

$t_{s}=250 \mathrm{~mm}$

Take $S=2.5 \mathrm{~m} \mathrm{\&} \mathrm{S}^{\prime}=0.75$

Flange width is controlled when handling \& transportation

$b_{f c} \geq \frac{L}{85} \mathrm{~mm} \rightarrow \mathrm{L}=$ shipping length $\approx 12 \mathrm{~m}$ 
$b_{f c} \geq \frac{12000}{85}=142 \mathrm{~mm} \geq 300 \mathrm{~mm} \rightarrow b_{f c} \geq 300 \mathrm{~mm}$

The minimum flange thickness for a straight bridge is $19 \mathrm{~mm}$, so take:

Thick flange upper $=20 \mathrm{~mm}$

Thick flange bottom $=20 \mathrm{~mm}$

So for web height $D=1800-20-20=1760 \mathrm{~mm}$

Minimum web thickness of $12 \mathrm{~mm}$, take $\mathrm{t}_{\mathrm{w}}=14 \mathrm{~mm}$

Check the flange proportion requirements:

$b_{f} \geq \frac{D}{6}=\frac{1760}{6}=293.33 \mathrm{~mm}$

Use $b_{f}=350$ for the upper and lower flanges

$\frac{b_{f}}{2 t_{f}} \leq 9.2=\frac{350}{2 \times 20}=8.75<9.2$ (top flens NSBA)

$\frac{b_{f}}{2 t_{f}} \leq 9.2=\frac{350}{2 \times 20}=8.75<9.2$ (bottom flens NSBA)

Then from the data above we get the following cross-section proportions:

Steel IWF 1800.300.14.20
$\mathrm{d}=1800 \mathrm{~mm}$
$b_{f} \quad=300 \mathrm{~mm}$
$\mathrm{t}_{\mathrm{w}} \quad=14 \mathrm{~mm}$
$\mathrm{t}_{\mathrm{f}} \quad=20 \mathrm{~mm}$
$\mathrm{t}_{\mathrm{b}} \quad=20 \mathrm{~mm}$
$\mathrm{L} \quad=40 \mathrm{~m}$
$\mathrm{F}_{\mathrm{c}^{\prime}} \quad=40 \mathrm{MPa}$
$\mathrm{F}_{\mathrm{y}}=345 \mathrm{MPa}$
$\mathrm{D}_{\mathrm{w}} \quad=1760 \mathrm{~mm}$
$\mathrm{E}_{\mathrm{c}} \quad=4700 \sqrt{f_{c^{\prime}}}=29725.41 \mathrm{MPa}$
$\mathrm{E}_{\mathrm{s}} \quad=200000 \mathrm{MPa}$
$\mathrm{n} \quad=\frac{E_{s}}{E_{c}}=6.728$

Examination of Proportion Limits for Profile Cross-section

The cross-section proportion must be checked to ensure the stability of the profile used meets the requirements. Determination of the cross-section proportion set in the AASHTO LRFD Bridge Design Specifications 2017 Article 6.10.2:

In accordance with AASHTO LRFD Bridge Design Specifications 2017 article

6.10.2.1.1-1

1. Proportion of Body Plate Without Stiffener

Calculated as follows:

$\frac{D_{w}}{t_{w}}=\frac{1760}{14}=125.71 \mathrm{~mm}$

Check web stability $=\frac{D_{w}}{t_{w}} \leq 150 \rightarrow 125.71 \leq 150$, then including slim web.

2. Proportion of Wing Plate Sections

In accordance with AASHTO LRFD Bridge Design Specifications 2017 article 6.10.2.2, for cross section of wing plate as follows:

- AASHTO LRFD 2017 6.10.2.2-1

$$
\frac{b_{f}}{2 t_{f}} \leq 12 \rightarrow \frac{300}{2.20}=7.5 \leq 12 \ldots \text { OK }
$$

- AASHTO LRFD 2017 6.10.2.2-2 $b_{f} \geq \frac{D_{w}}{6} \rightarrow \frac{1760}{6}=293.33 \mathrm{~mm} \rightarrow 0.3 \mathrm{~m} \geq 0.293 \mathrm{~m} \ldots \mathrm{OK}$

- AASHTO LRFD 2017 6.10.2.2-3

$t_{f} \geq 1.1 t_{w} \rightarrow 1.1 t_{w}=0.015 \mathrm{~m}$

$t_{f}=0.020 \mathrm{~m}$

$0.020 \geq 0.015 \ldots . .0 K$

- $\quad$ AASHTO LRFD 2017 6.10.2.2-4 


$$
\begin{aligned}
& 0.1 \leq \frac{I_{y c}}{I_{y t}} \leq 10 \\
& I_{y c}=\frac{t_{f} \cdot b_{f}^{3}}{12}=\frac{0.020 \cdot 0.0252}{12}=0.000042 \mathrm{~m}^{4} \\
& I_{y t}=\frac{t_{f} \cdot b_{f}^{3}}{12}=\frac{0.020 \cdot 0.0252}{12}=0.000042 \mathrm{~m}^{4} \\
& 0.1 \leq \frac{I_{y c}}{I_{y t}} \leq 10 \\
& 0.1 \leq 1 \leq 10
\end{aligned}
$$

Modeling of Non-composite Bridges

Modeling of non-composite bridges was carried out with the help of CSI Bridge v20.2.0 program. Figure 10 shows the 3D appearance of the non-composite bridge model.

Fig. 10 3D Modeling Non-composite bridge

\section{Structure Analysis}

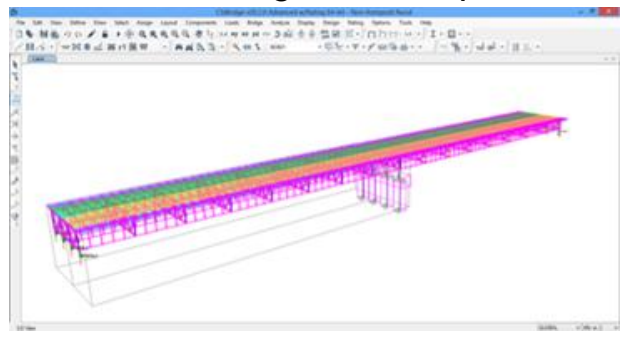

The following results of structural analysis that work on non-composite bridges due to strong combinations resulting from modeling using CSiBridge software are as follows:

1. Moment Field in Girder Interior 1

Fig. 11 Field Moment Non-Composite Steel Structures

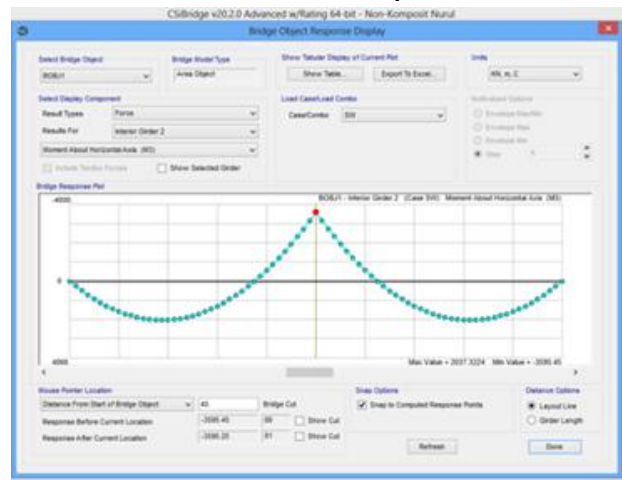

The value of internal forces in the interior girder 1

$\mathrm{M} 1=-3595.38$

The value of internal forces in the interior girder 2

M2 $=-3595.25$

The value of internal forces in the interior beam 1

$\mathrm{M} 1=-3593.4$

The value of internal forces in the interior beam 2

$\mathrm{M} 2=-3593.32$

The value of internal forces in the interior slab 1

$\mathrm{M} 1=-0.0118$

The value of internal forces in the interior slab 2

M2 $=-0.0118$

From the above data, the highest Flexural Strength $\left(\mathrm{M}_{\mathrm{u}}\right)$ value is taken, which is found in the interior of girder 1 , which is: $-3595.38 \mathrm{kNm}$ 
2. Slide Field On Girder Interior 1

Fig. 12 Shear Force Non-Composite Steel Structures

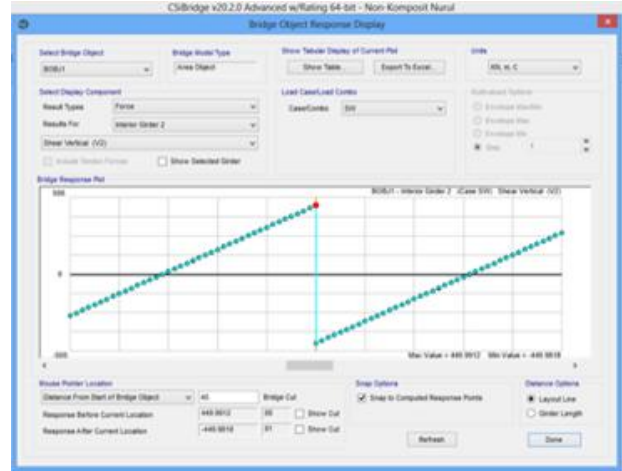

The value of the shear force on the interior of the girder 1

$\mathrm{V} 1=-449.9968$

The value of the shear force on the interior of the girder 2

$\mathrm{V} 2=-449.9818$

The value of the shear force on the interior beam 1

$\mathrm{V} 1=-442.4905$

The value of the shear force on the interior beam 2

$\mathrm{V} 2=-442.4755$

The value of the shear force on the interior of the slab 1

$\mathrm{V} 1=-7.5063$

The value of the shear force on the interior of the slab 2

$\mathrm{V} 2=-7.5063$

From the above data, the largest Shear Force $\left(\mathrm{V}_{\mathrm{u}}\right)$ value is taken, which is found in the interior of girder 1, which is: $-449.9968 \mathrm{kNm}$

\section{Calculation of Inertia and Center of Cross Section}

In the calculation of inertia and cross-section emphasis is done using Microsoft Excel and obtained the following data:

Non Composite Elastic Flexural Section Properties

Fig. 13 Non Composite Elastic Flexural Section Properties

\begin{tabular}{|c|c|c|c|c|c|}
\hline \multicolumn{6}{|c|}{ Aboua $-x$} \\
\hline Part & $A$ & $\bar{x}$ & 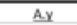 & $A \times(y, Y b)^{2}$ & $\operatorname{lox}$ \\
\hline Top Flange. & 6000.0 & 1790.0 & 107400000 & 47526000000 & 20000000 \\
\hline web & 246400 & 9000 & 221760000 & 0.0 & 6360005333 \\
\hline Bottom Flange & 6000.0 & 10.0 & 600000 & 475260000000 & 2000000 \\
\hline Covere plate & 00 & 0.0 & 0.0 & 0.0 & 0.0 \\
\hline loosy stiff 1 & 0.0 & 00 & 0.0 & 0.0 & 0.0 \\
\hline \multirow[t]{5}{*}{ Cone Stiff? } & 00 & 00 & & & 00 \\
\hline & 36640.0 & & 329760000 & 950520000000 & 6360805333 \\
\hline & $A$ & 36640.0 & $m m^{2}$ & & \\
\hline & $x_{4 a t}$ & 900.0 & $\mathrm{~mm}$ & & \\
\hline & 1 & 158660053333. & $\mathrm{~mm}^{*}$ & & \\
\hline \multicolumn{6}{|c|}{ Abou $\cdot \gamma$} \\
\hline Part & A & $\underline{x}$ & $\underline{A x}$ & A. $(x-x)^{2}$ & loy \\
\hline Top flanger & 6000.0 & 0.0 & 0.0 & 0.0 & 45000000.0 \\
\hline Wob & 24640.0 & 0.0 & 0.0 & 0.0 & 4024533.3 \\
\hline Botrom Flange & 6000.0 & 0.0 & 0.0 & 0.0 & 450000000 \\
\hline Cover plate & 00 & 0.0 & 0.0 & 0.0 & 0.0 \\
\hline congstitt 1 & 0.0 & 0.0 & 0.0 & 0.0 & 0.0 \\
\hline \multirow[t]{5}{*}{ conessitt2 2} & 00 & 0.0 & 0.0 & 0.0 & $\infty$ \\
\hline & 366400 & & 0.0 & 0.0 & 90402453.3 \\
\hline & $x^{2}$ & 36640 & $\mathrm{~mm}^{2}$ & & \\
\hline & $x_{t a t}$ & 0.0 & $m m$ & & \\
\hline & 1, & 904024533 & $\mathrm{~mm}^{*}$ & & \\
\hline
\end{tabular}


Non Composite Elastic Torsional Section Properties

Fig. 14 Non Composite Elastic Torsional Section Properties

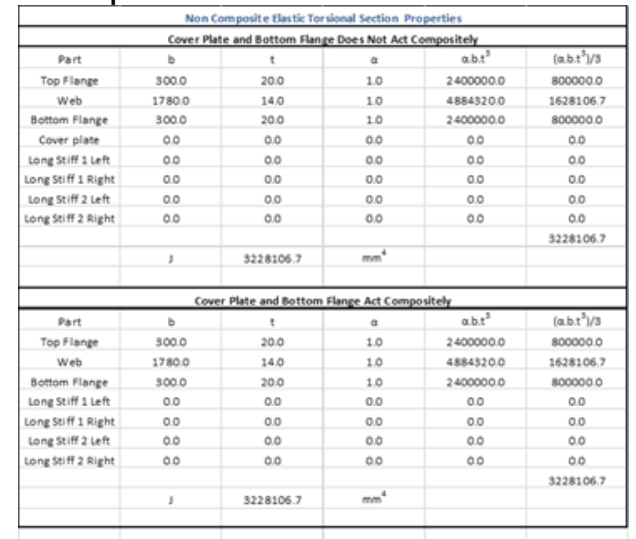

Girder moment of inertia about $x=\Sigma\left(\mathrm{A} x(y-Y b)^{2}+\mathrm{lox}\right.$

$$
\begin{aligned}
& =9505200000.0+6360805333 \\
& =15866005333.3 \mathrm{~mm}^{4}
\end{aligned}
$$

Girder moment of inertia about $y=\Sigma\left(A x(x-X)^{2}+\right.$ loy $=0+90402453.3$

$$
=90402453.3 \mathrm{~mm}^{4}
$$

Girder top elastic section modulus about $x=\frac{I_{x}}{(H+t c p-Y c . g . c)}=\frac{15866005333.3}{(1800+0-900)}$

$$
=17628894.8 \mathrm{~mm}^{3}
$$

Girder bottom elastic section modulus about $x=\frac{I_{x}}{(H+t c p-Y c . g . c)}$

$$
\begin{aligned}
& =\frac{15866005333.3}{(1800+0-900)} \\
& =17628894.8 \mathrm{~mm}^{3}
\end{aligned}
$$

Girder left elastic section modulus about $y=\frac{I_{y}}{\left(B_{f t} / 2\right)}=\frac{90402453.3}{(300 / 2)}$

$$
=602683.0 \mathrm{~mm}^{3}
$$

Girder right elastic section modulus about $y=\frac{I_{y}}{\left(B_{f t} / 2\right)}=\frac{90402453.3}{(300 / 2)}$

$$
=602683.0 \mathrm{~mm}^{3}
$$

Girder plastic section modulus about $x=\frac{M p_{x}}{f_{y} \cdot 10^{6}}=\frac{7859.65}{345 \cdot 10^{6}}$

$$
=22781600 \mathrm{~mm}^{3}
$$

Girder plastic section modulus about $y=\frac{M p_{y}}{f_{y} \cdot 10^{6}}=\frac{340.25}{345 \cdot 10^{6}}$

$$
=986240 \mathrm{~mm}^{3}
$$

Radius of gyration about $x=\sqrt[2]{\frac{I_{x}}{A_{g}}}=\sqrt[2]{\frac{15866005333.3}{36640}}$

$$
=658 \mathrm{~mm}
$$

Radius of gyration about $y=\sqrt[2]{\frac{I_{y}}{A_{g}}}=\sqrt[2]{\frac{90402453.3}{36640}}$

$$
=49.7 \mathrm{~mm}
$$

Centroid from bottom $=\frac{\Sigma A . y}{\Sigma A}=\frac{32976000}{36640}=900 \mathrm{~mm}$

Centroid from mid of $w e b=\frac{\Sigma A \cdot x}{\Sigma \mathrm{A}}=\frac{0}{36640}=0 \mathrm{~mm}$

Torsional Constant $=\sum \frac{\left(\alpha . b \cdot t^{3}\right)}{3}=\frac{9,684,320.00}{3}=3228106.7 \mathrm{~mm}$

Warping Constant $=\sum \frac{\left(\alpha . b . t^{3}\right)}{3}=\frac{9,684,320.00}{3}=71289000000000 \mathrm{~mm}$ 
Section Classification

Straight bridges with non-composite cross sections must be checked for:

In Accordance with AASHTO LRFD Bridge Design Specification 2017 (6.10.6.2.2-2)

$\mathrm{f}_{\mathrm{yf}}=\mathrm{f}_{\mathrm{y}}=345 \mathrm{MPa}$

$\mathrm{f}_{\mathrm{yf}} \leq 485 \mathrm{MPa}$

$345 \leq 485 \mathrm{MPa}$

OK

In Accordance with AASHTO LRFD Bridge Design Specification 2017 (6.10.6.2.2-1)

2. $\frac{\mathrm{D}_{c p}}{t_{w}} \leq 3.76 \sqrt{\frac{\mathrm{E}_{s}}{f_{c^{\prime}}}}$

Where:

$\mathrm{ys}_{\text {top }} \quad=0.59 \mathrm{~m}$

$D_{c p}=y_{\text {top }}-t_{f}=0.57 m$

So,

2. $\frac{\mathrm{D}_{c p}}{t_{w}}=\frac{1140}{14}=81.42 \mathrm{~mm}$

$3.76 \sqrt{\frac{E_{s}}{f_{c^{\prime}}}} \quad=265,87$

$81.42 \leq 265,87$ .OK

Non-Composite Plate Girder Design Based on AASHTO LRFD Bridge Design Specification $2017^{33}$

Check the State of the Cross Section

During construction

Due to flexure

1. Upper Flens

Style that works:

$\mathrm{M}_{\text {girder }}=3595.38 \mathrm{kN} \cdot \mathrm{m}$

$M_{\text {plate }}=781.25 \mathrm{kN} \cdot \mathrm{m}$

$\mathrm{I}_{\mathrm{s}}=15866005333.3 \mathrm{~mm}^{4}$

Tension on the upper wing:

$\sigma_{\text {topflange }}=\frac{(1.1 \mathrm{M} \text { girder }+1.3 \mathrm{M} \text { pelat }) \cdot \mathrm{ystop}}{I_{S}}=184.84 \mathrm{MPa}$

Lateral bending stress values are assumed to be $f 1=0$

2. Check the nominal melting resistance of the upper wing

Check against the requirements 6.10.3.2.1

Tension on the upper wing

$\mathrm{f}_{\mathrm{bu}}=$ otopflange $=184.84 \mathrm{MPa}$

Reduction factor for bending

$\emptyset_{\mathrm{f}}=0.90$

For cross section with material

a kind, $R h$ is taken 1 ,

$\mathrm{Rh}=1$

Nominal melting wing based on AASHTO

2017 LRFD (6.10.3.2.1-1)

$\emptyset_{\mathrm{f}} \cdot R h \cdot F y=310.5 \mathrm{MPa}$

$\mathrm{f}_{\mathrm{bu}}+F 1 \leq \emptyset_{\mathrm{f}} \cdot R h \cdot F y$

$184.84+1 \leq 310.5 \mathrm{MPa}$ OK

Ratio $=\frac{\mathrm{f}_{b u+f 1}}{\emptyset_{\mathrm{f}} \cdot R h \cdot F y}=0.599$

3. Check Bending Resistance To Upper Flens

Local buckling prisoners

Calculate the ratio of the tension of the wing presses to the space according to AASHTO LRFD 2017 (6.10.8.2.2-3) 
$\lambda_{\mathrm{f}}=\frac{\mathrm{b}_{\mathrm{f}}}{2 t f}=\frac{0,300}{2 \cdot 0,02}=7.5$

Calculate the limit of the slope to plate ratio

Compact compressive wing to suit AASHTO LRFD

2017 (6.10.8.2.2-4)

$\lambda_{\mathrm{pf}}=0.38 \sqrt{\frac{\mathrm{E}_{s}}{f_{y}}}=9.149$

If $\lambda_{\mathrm{f}} \leq \lambda_{\mathrm{pf}}$

$7.5 \leq 9.149$ then local buckling prisoners from

upper wing is

$\mathrm{F}_{\mathrm{nc} \mathrm{FLB}}=\mathrm{R}_{\mathrm{b}} \mathrm{R}_{\mathrm{h}} \mathrm{f}_{\mathrm{y}}$

Calculate the limit of slenderness ratio for plates

noncompact body

$\lambda_{\text {rw }}=5.7 \sqrt{\frac{E_{s}}{f_{y}}}=137.24$

Calculate the value of the web loading shedding factor $\left(\mathrm{R}_{\mathrm{b}}\right)$

Factor $\mathrm{R}_{\mathrm{b}}=1$ for strength checking

when constructibility and if conditions

the following are met:

- For a positive bending composite cross section without a longitudinal stiffner that meets the following requirements:

$\frac{\mathrm{D}}{t_{w}} \leq 150$

$\frac{1760}{14}=125.71 \leq 150$

OK

Then the local buckling resistance in the upper wing according to AASHTO LRFD 2017 (6.10.8.2.2-1) is:

$\mathrm{F}_{\mathrm{nc}} \mathrm{FLB}=\mathrm{R}_{\mathrm{b}} \mathrm{R}_{\mathrm{h}} \mathrm{f}_{\mathrm{yc}}=345 \mathrm{MPa}$

- Lateral torque bend resistance

$\mathrm{L}_{b}=5 \mathrm{~m}$

Effective grating radius for lateral torsion ( $\mathrm{rt}$ ) bending according to AASHTO LRFD 2017 (6.10.8.2.3-9)

$\mathrm{r}_{\mathrm{t}}=\frac{\mathrm{bf}}{\sqrt{12\left(1+\frac{1}{3} \cdot \frac{D . t w}{b f . t f}\right.}}=\frac{0,300}{\sqrt{12\left(1+\frac{1}{3} \cdot\left(\frac{1,760 \cdot 0,014}{0,300 \cdot 0,020}\right)\right)}}=0.081 \mathrm{~m}$

Length without bracing (Lp) according to AASHTO LRFD 2017 (6.10.8.2.3-4)

$L_{p}=1.0 . \mathrm{rt} \cdot \sqrt{\frac{E_{s}}{f_{y}}}=1.0 \cdot 0.081 \cdot \sqrt{\frac{200000}{345}}=1.950 \mathrm{~m}$

Length without bracing $\left(L_{r}\right)$ according to AASHTO LRFD 2017 (6.10.8.2.3-5)

$L_{r}=\pi r t \cdot \sqrt{\frac{E_{s}}{f_{y}}}=3,14 \cdot 0,081 \cdot \sqrt{\frac{200000}{345}}=6.052 \mathrm{~m}$

If $L_{p}<L_{b}<L_{r}$ then:

$\mathrm{Cb}=1$

$\mathrm{F}_{\mathrm{yr}}=0.7 . \mathrm{F}_{\mathrm{y}}=0.7 \cdot 345=241.5 \mathrm{MPa}$

$\mathrm{F}_{\mathrm{nc} \mathrm{LTB}}=\mathrm{C}_{\mathrm{b}}\left[1-\left(1-\frac{F y r}{R h \cdot F y c}\right)\left(\frac{L b-L p}{L r-L p}\right)\right] \cdot \mathrm{R}_{\mathrm{h}} \mathrm{f}_{\mathrm{yc}} \leq \mathrm{R}_{\mathrm{b}} \mathrm{R}_{\mathrm{h}} \mathrm{f}_{\mathrm{yc}}$

$=1\left[1-\left(1-\frac{241.5}{1.345}\right)\left(\frac{2-1.950}{6.052-1.950}\right)\right] \cdot 345 \leq 345$

$=343.76 \leq 345$

$\mathrm{OK}$

Use the smallest $F_{n c}$ value from 2 conditions, so that:

$\mathrm{F}_{\mathrm{nc}}=\min \left(\mathrm{F}_{\mathrm{nc}} \mathrm{FLB}, \mathrm{F}_{\mathrm{nc}} \mathrm{LTB}\right)=343.76 \mathrm{MPa}$

$\mathrm{F}_{\mathrm{bu}}=184.84 \mathrm{MPa}$

$\mathrm{F}_{\mathrm{bu}}+\frac{1}{3} . \mathrm{f} 1=184.84 \mathrm{MPa}$

$\emptyset_{\mathrm{f}} . \mathrm{F}_{\mathrm{nc}}=0.90 \times 343.76 \mathrm{MPa}=309.38 \mathrm{MPa}$

$F_{b u}+1 / 3 . f 1 \leq \emptyset_{f} . F_{n c}$ 
$184.84 \mathrm{MPa} \leq 309.38 \mathrm{MPa} \ldots \ldots \ldots \ldots \ldots . . \mathrm{OK}$

4. Bottom Flens

Ratio $=\left(\frac{\mathrm{f}_{b u+\frac{1}{3} f 1}}{\emptyset_{\mathrm{f}} \cdot F n c}\right)=\left(\frac{184.84+0}{309.38}\right)=0.597$

$\mathrm{yS}_{\text {bot }}=0.9 \mathrm{~m}$

$\sigma_{\text {bottlange }}=\frac{(1.1 \text { Mgirder+1.3 Mpelat }) \cdot y s_{\text {bot }}}{I_{S}}=184.84 \mathrm{MPa}$

$\mathrm{F}_{\text {bu }} \quad=\sigma_{\text {bottlange }}=184.84 \mathrm{MPa}$

The tensile wing plate must meet the following equation:

$\mathrm{f}_{\mathrm{bu}}+\mathrm{f}_{1} \leq \emptyset_{\mathrm{f}} \cdot R h . F y$

$\emptyset_{\mathrm{f}} \cdot R h \cdot F y=0.90 \cdot 1 \cdot 345=310.5 \mathrm{MPa}$

$\mathrm{F}_{\mathrm{bu}} \leq \emptyset_{\mathrm{f}} \cdot R h \cdot F y$

184.84 MPa $\leq 310.5 \mathrm{MPa}$ .OK

Ratio $\frac{\mathrm{f}_{b u}}{\emptyset_{\mathrm{f}} \cdot R h \cdot F y}=\frac{184.84}{310,5}=0.595$

5. Body Plates (web)

To ensure that bending does not occur on the web during the construction process the requirements in equation 6.10.3.2.1-3 must be met,

$\mathrm{F}_{\mathrm{bu}} \leq \varnothing \mathrm{F}_{\mathrm{crw}}$

Bend the bending coefficient

$\mathrm{K}=\frac{9}{\left(\frac{D C}{D}\right)^{2}}=\frac{9}{\left(\frac{880}{1760}\right)^{2}}=36$

Prisoners bend in the body

$\mathrm{F}_{\mathrm{crw}}=\frac{0.95 . \mathrm{Es} . \mathrm{k}}{\left(\frac{D}{t w}\right)^{2}}=\frac{0.95 .200000 .36}{\left(\frac{1760}{14}\right)^{2}}=432.80$

However, the $F_{\text {crw }}$ value cannot be more

big from:

$F_{y e}=F_{y}=345 \mathrm{MPa}$

$\mathrm{F}_{\mathrm{yw}}=\mathrm{F}_{\mathrm{y}}=345 \mathrm{MPa}$

$R_{h} \cdot f_{y e}=345 \mathrm{MPa}$

$\frac{\mathrm{f}_{y w}}{0.7}=492.857 \mathrm{MPa}$

then the bending prisoners in the body are:

$\mathrm{F}_{\text {crw }}=\min \left(f_{\text {crw }}, R_{h} \cdot f_{y e}, \frac{\mathrm{f}_{y w}}{0.7}\right)=345 \mathrm{MPa}$

$\emptyset_{\mathrm{f}} \cdot \mathrm{F}_{\mathrm{crw}}=0.90 \times 345=310.5 \mathrm{MPa}$

Check bending resistance in the body

$\mathrm{F}_{\mathrm{bu}} \leq \emptyset_{\mathrm{f}} . \mathrm{F}_{\mathrm{crw}}$

184.84 MPa $\leq 310.5 \mathrm{MPa}$ OK

Ratio $=\frac{\mathrm{f}_{b u}}{\emptyset_{\mathrm{f}} \cdot F_{c r w}}=0.595$

In this study, the examination of the cross-section boundary conditions due to shear, service boundary conditions and fatigue boundary conditions are not included or not calculated. And go directly to the calculation phase of the strong boundary conditions. Strong Boundary Conditions

Due to Flexure

1. Determination of Plastic Neutral Axes Based on Table D.6.1.1 AASHTO LRFD 2017

Compressed wing width

$\mathrm{b}_{\mathrm{cf}}=300 \mathrm{~mm}$

Compressed wing thickness $t_{c f}=20 \mathrm{~mm}$

Wing width

$\mathrm{b}_{\mathrm{tf}}=300 \mathrm{~mm}$

Wing thickness

$\mathrm{t}_{\mathrm{ft}}=20 \mathrm{~mm}$

Web height

$D_{\mathrm{w}}=1760 \mathrm{~mm}$

Web thickness

$\mathrm{t}_{\mathrm{w}}=14 \mathrm{~mm}$

Force plate press plate

$P_{s}=0.85 . f_{c^{\prime}} \cdot b_{\mathrm{ef}} \cdot h_{s}=1700 \mathrm{kN}$

Axial force on the reinforcement of the deck plate

$P_{\mathrm{rt}}=0 \mathrm{kN}$ 
Axial force on the reinforcement under the deck plate $P_{r b}=0 \mathrm{kN}$

Axial force on the upper wing $P_{c}=B_{c f} \cdot t_{c f} \cdot f_{y}=2484 \mathrm{kN}$

Axial force on the web $\quad P_{w}=D_{w} \cdot t_{w} \cdot f_{y}=8500.5 \mathrm{kN}$

Axial force on the lower wing $P_{t}=b_{t f} \cdot t_{t f} \cdot f_{y}=2070 \mathrm{kN}$

Case I

$\mathrm{P}_{\mathrm{t}}+\mathrm{P}_{\mathrm{w}}=10570.5 \mathrm{kN}$

$P_{c}+P_{s}+P_{r b}+P_{r t}=4184 k N$

Case II

$\mathrm{P}_{\mathrm{t}}+\mathrm{P}_{\mathrm{w}}+\mathrm{P}_{\mathrm{c}}=13054.5 \mathrm{kN}$

$P_{s}+P_{r b}+P_{r t}=1700 k N$

Because Case II meets the requirements, the PNA is in the upper wing, so:

$Y=\left(\frac{t_{c f}}{2}\right) \cdot\left(\frac{P_{w}+P_{t}-P_{s}-P_{r t}-P_{r b}}{P_{c}}+1\right)$

$Y=89.9 \mathrm{~mm}$

2. Check ductility according to AASHTO LRFD 2017 6.10.7.3-1

$D_{p} \leq 0.42 D_{t}$

Distance from the top edge of the concrete deck to the neutral axis of the composite cross section at a plastic moment $\left(D_{p}\right)$

$D_{p}=h_{s}+t_{c f}+Y=129.9 \mathrm{~mm}$

Total height of composite cross section $\left(D_{t}\right)$

$\mathrm{D}_{\mathrm{t}}=\mathrm{D}+\mathrm{h}_{\mathrm{s}}=1.82 \mathrm{~m}$

$0.42 \mathrm{D}_{\mathrm{t}}=764.4 \mathrm{~mm}$

$D_{p} \leq 0.42 D_{t}$

$129.9 \leq 764.4 \ldots$ OK

3. Check steel compact section according to AASHTO LRFD 2017 6.10.7.1.2-1

$\mathrm{D}_{\mathrm{p}} \leq 0.1 \mathrm{D}_{\mathrm{t}}$

$0.1 \mathrm{D}_{\mathrm{t}}=182 \mathrm{~mm}$

$182 \leq 764.4 \ldots$ OK

4. Calculation of AASHTO LRFD 2017 plastic moment D6.1-2

$D_{t}=t_{c f}+D_{w}+t_{t t} / 2-Y=1700.1 \mathrm{~mm}$

$\mathrm{d}_{\mathrm{s}}=\mathrm{h}_{\mathrm{s}} / 2+\mathrm{t}_{\mathrm{cf}}+\mathrm{Y}=119.9 \mathrm{~mm}$

$d_{w}=D_{w} / 2+t_{t f}-Y=810.1 \mathrm{~mm}$

$\mathrm{d}_{\mathrm{rt}}=0 \mathrm{~mm}$

$\mathrm{d}_{\mathrm{rb}}=0 \mathrm{~mm}$

So that the plastic moment can be calculated by:

$$
M_{p}=\frac{P_{c}}{2 \cdot t_{c f}} \cdot\left[Y^{2}-\left(t_{c f}-Y\right)^{2}\right]+P_{s} \cdot d_{s}+P_{r t} \cdot d_{r t}+P_{r b} \cdot d_{r b}+P_{w} \cdot d_{w}+P_{t} \cdot d_{t}
$$

$M_{p}=7859.652 \mathrm{kN} \cdot \mathrm{m}$

Calculate the nominal moment value

$M_{n}=M_{p} \cdot\left(1.07-0.7 \cdot \frac{D_{p}}{D_{t}}\right)$

$M_{n}=8016.843 \mathrm{kN} \cdot \mathrm{m}$

$M_{u}=3595.38 \mathrm{kN} \cdot \mathrm{m}$

$\emptyset_{\mathrm{f}}=1.0$

$\emptyset_{\mathrm{f}} \cdot M_{n}=8016.843 \mathrm{kN} \cdot \mathrm{m}$

5. Check the cross-section capacity according to AASHTO LRFD 2017 6.11.7.1.1-1

$M_{u} \leq \emptyset_{\mathrm{f}} \cdot M_{n}$

$3595.38 \leq 8016.843 \mathrm{kN} . \mathrm{m} \ldots$.. OK

Ratio $=\frac{M_{u}}{\emptyset_{\mathrm{f}} \cdot M_{n}}=0.449$ 
Design of Non-Composite Girder Plate Based on SNI 1729: 2015 $5^{[4]}$

Components of Profile Structure I Double Symmetrical And Single Symmetrical With A Curved Slim Body On Major Axis (F5 - SNI 1729: 2015)

The nominal flexural strength $M_{n}$, must be the lowest value obtained in accordance with the boundary conditions of the compressed wing melting, torsion-lateral bending, localized compressive wing bending and tensile wing melting.

1. Melt Wings Press

$M_{n}=F_{y} S_{x t}$

Looking for $R_{p g}$ :

$R_{p g}=1-\frac{a_{w}}{1200+300 a_{w}}\left(\frac{h_{c}}{t_{w}}-5.7 \sqrt{\frac{E}{F_{y}}}\right) \leq 1.0$

Meanwhile, to search for $a_{w}$ itself $=\frac{h_{c} \cdot t_{w}}{b_{f c} \cdot t_{f c}}=4.2$

$R_{p g}=1-\frac{4.2}{1200+300 \cdot 4.2}\left(\frac{1800}{300}-5.7 \sqrt{\frac{20000}{345}}\right) \leq 1.0$

$R_{p g}=-8.68 \leq 1.0$

Maka $M_{n}=R_{p g} F_{y} S_{x c}$

$M_{n}=-8.68 .345 .17628894 .8$

$M_{n}=52.79 \times 10^{10} \mathrm{Nmm}=52791.49 \mathrm{kNm}$

2. Bend Lateral Torque

For cross sections with compact wings, the boundary state of the local bending of the compressed wing should not be used. Therefore in this study for compact wing cross sections it should not be used.

3. Bend Local Wing Press

$M_{n}=R_{p g} F_{c r} S_{x c}$

Look for the $F_{c r}$ value to bend the local wing press:

- $F_{c r}=\left[F_{y}-\left(0,35 F_{y}\right)\left(\frac{\lambda-\lambda_{p f}}{\lambda_{r f}-\lambda_{p f}}\right)\right]$

- $\lambda=\frac{b_{f c}}{2 t_{f c}}=\frac{300}{2.20}=7.50$

- $\lambda_{p f}=\lambda_{p}=0,38 \sqrt{\frac{E}{F_{y}}}=9.15$

- $\lambda_{r f}=\lambda_{r}=0.95 \sqrt{\frac{K_{c} E}{F_{L}}}$

$K_{c}=\frac{4}{\sqrt{h / t_{w}}}=0.36$

$F_{L}=0.7 \cdot F_{y}=241.5$

$\lambda_{r f}=\lambda_{r}=0.95 \sqrt{\frac{K_{c} E}{F_{L}}}=16.40$

So,

$F_{c r}=\left[F_{y}-\left(0,35 F_{y}\right)\left(\frac{\lambda-\lambda_{p f}}{\lambda_{r f}-\lambda_{p f}}\right)\right]=321.44$

So that,

$M_{n}=R_{p g} F_{c r} S_{x c}$

$M_{n}=49186365278.36 \mathrm{Nmm}$ 
$=49186.37 \mathrm{kNm}$

4. Melt Wing Pull

$M_{n}=F_{y} S_{x t}$

$M_{n}=345.17628894 .8$

$M_{n}=6081968706 \mathrm{Nmm}$

$M_{n}=6081.97 \mathrm{kNm}$

From the results of the whole calculation, the smallest $M_{n}$ value is taken, the $M_{n}$ value which is in the tensile wing melting of $6081.97 \mathrm{kNm}$.

Comparation of Similarities and Differences

Below is a table of comparative results between the AASHTO LRFD Bridge Design Specification 2017 code with the SNI 1729: 2015 code in the planning of bending noncomposite plate girder bridge design:

Table 3.3 Comparative Results Table

\begin{tabular}{|c|c|c|c|c|c|c|}
\hline \multirow[b]{2}{*}{ No } & \multirow[b]{2}{*}{ Code } & \multicolumn{4}{|c|}{ Nilai } & \multirow{2}{*}{ Status } \\
\hline & & $M_{u}$ & Satuan & ${\sigma M_{n}}_{n}$ & Satuan & \\
\hline 1 & \begin{tabular}{|l|} 
AASHTO LRFD Bridge Design \\
Spesifications 2017 \\
\end{tabular} & 3595.38 & kNm & 8016.84 & kNm & OK \\
\hline 2 & SNI 17292015 & 3595.38 & kNm & 6081.97 & $\mathrm{kNm}$ & OK \\
\hline
\end{tabular}

\section{CLOSING}

In this chapter, the authors provide conclusions and suggestions relating to the results that the authors examined. The conclusion was obtained from the results of the analysis and interpretation of existing data. Meanwhile, suggestions are given as reference material in subsequent studies.

\section{CONCLUSIONS}

From the comparative studies that have been made, some conclusions can be drawn, as follows:

1. In planning the plate girder bending using AASHTO LRFD Bridge Design Specifications 2017 gives a greater $Ø \mathrm{Mn}$ value so that a smaller profile dimension can be used than the results of planning using SNI 1729: 2015.

2. On the contrary, planning for plate girder bending using SNI 1729: 2015 results in a smaller ØMn value so that the dimensions of the profile used are greater than the results of planning using AASHTO LRFD Bridge Design Specifications 2017.

3. The results of planning the flexible plate girder using the AASHTO LRFD Bridge Design Specifications 2017 regulations are much safer when compared to the results of the design using SNI 1729: 2015 regulations.

From the values obtained it can be concluded that the two regulations namely AASHTO LRFD Bridge Design Specifications 2017 and SNI 1729: 2015 in the stability planning of noncomposite plate girder bridges produce a safe and strong plan because they meet the applicable provisions namely Moment $(\mathrm{Mu}<\varnothing \mathrm{Mn})$.

\section{Suggestions}

From the comparative studies that have been carried out, several things that can be developed in further research are as follows:

1. It is necessary to compare non-composite bridge planning based on AASHTO LRFD Bridge Design Specifications 2017 and SNI 1729: 2015 for Constructability, Serviceability, Fatigue and Fracture. 
2. It is necessary to compare the planned budget of the design results of the noncomposite plate girder bridge design based on AASHTO LRFD Bridge Design Specifications 2017 and SNI 1729: 2015.

\section{REFERENCES}

[1] Bakosurtanal. Badan Informasi Geospasial. Bakosurtanal. [Online] 2014. http://www.bakosurtanal.go.id.

[2] Supriyadi, Bambang and Muntohar, A. S. Jembatan. Yogyakarta : Beta Offset, 2007.

[3] AASHTO. AASHTO LRFD Bridge Design Specifications 8th Edition. Washington, DC : American Association of State Highway and Transportation Officials, 2017.

[4] Indonesia, Standar Nasional. SNI 1729:2015 Spesifikasi untuk Bangunan Gedung Baja Struktural. Jakarta : Badan Standardisasi Nasional, 2015.

[5] AISC. An American National Standard ANSI/AISC 360-10 : Load Specification for Structural Steel Buildings. Chicago : American Institute of Steel Construction, Inc., 2010.

[6] Dewobroto, W. Struktur Baja Perilaku, Analisis \& Desain-AISC 2010 Edisi ke-2. Tanggerang : Penerbit Jurusan Teknik Sipil UPH, 2016.

[7] Setiawan, A. Perencanaan Struktur Baja Dengan Metode LRFD. Semarang : Erlangga, 2008.

[8] Indonesia, Standar Nasional. SNI 1725:2016 Pembebanan Untuk Jembatan. Jakarta : Badan Standardisasi Nasional, 2016.

[9] Situstekniksipil.com. Klasifikasi Jembatan. Situstekniksipil. [Online] 23 October 2017. https://www.situstekniksipil.com/2017/10/klasifikasi-jembatan.html.

[10] Testindo.com. Penjelasan Konstruksi Jembatan, Lengkap!!! Testindo.com. [Online] 2 July 2018. https://testindo.com/article/359/konstruksi-jembatan.

[11] Essen, Donald. Sesi 06 - Perencanaan Struktur Baja Berdasarkan AASHTO LRFD Bridge Design Specifications 8th Edition. Pertamina University, Jakarta, Jakarta, Indonesia : s.n., 2-5 September 2019 